\title{
Experimental infection of horses with Vaccinia virus
}

\author{
Infecção experimental de equinos com o vírus Vaccínia
}

\author{
Claudio Henrique Gonçalves Barbosa ${ }^{\mathrm{I}}$ Fabiano José Ferreira de Sant'Ana ${ }^{\mathrm{I}}{ }^{*}$ \\ Juliana Felipetto Cargnelutti"II Eduardo Furtado Flores ${ }^{\text {III }}$ Antônio Raphael Teixeira Neto ${ }^{\text {II }}$ \\ Rosália Bezerra de Santana ${ }^{I I}$ Janildo Ludolf Reis Junior ${ }^{\text {IV }}$
}

\section{ABSTRACT}

Vaccinia virus (VACV) is the etiologic agent of bovine vaccinia, an emerging zoonotic disease with potential health issues for dairy herds and humans. VACV may occasionally infect other species, including horses. In this sense, an outbreak of VACV disease in horses was described in Pelotas, RS, in 2008, where a co-infection with two VACV strains (named Pelotas Virus 1 [P1V] and Pelotas Virus 2 [P2V]) was detected. Considering the rare occurrence of VACV infection in horses, the objective of this study was to investigate the susceptibility and pathogenesis of VACV infection in this species. Six adult horses were inoculated with VACV P1V or P2V $\left(10^{6.3} \mathrm{TCID}_{50} / \mathrm{ml}\right)$ through scarification of the nasolabial surface and monitored for virological and clinical aspects during 28 days. Four inoculated horses (4/6) developed mild lesions in the site of inoculation. Ulcers and scabs restricted to inoculated areas were observed between days 2 and 8 post-inoculation (pi). Microscopically there were acanthosis, ballooning degeneration of the stratum spinosum, necrosis and loss of the epidermis. Infiltration of neutrophils, macrophages and lymphocytes were observed in the dermis. Intracytoplasmic eosinophilic inclusions were infrequently observed in degenerate keratinocytes from adjacent necrotic areas. Virus shedding was detected between days 4 and 8 pi by PCR and virus isolation (infectious virus) from the lesions of one horse inoculated with P2V. No neutralizing antibodies were detected in inoculated animals at day 28 pi. In summary, inoculation of horses with VACV P1V and P2V isolates resulted in a low level of replication and at low frequency, with mild cutaneous lesions, when compared with the course of infection of other susceptible species to VACV. Therefore, horses possibly have a low potential for viral maintenance and transmission to other species, albeit being susceptible to VACV infection.

Key words: $V A C V$, experimental infection, horses, bovine vaccinia.

\section{RESUMO}

$O$ vírus Vaccinia (VACV) é o agente etiológico da vaccínia bovina, uma doença zoonótica re-emergente e de importância sanitária e econômica para rebanhos leiteiros. $O$ $V A C V$ também pode ocasionalmente infectar outras espécies, incluindo equinos. Nesse sentido, um surto de VACV em equinos foi descrito em Pelotas, RS, em 2008, no qual uma coinfecção com dois isolados de VACV (denominados Pelotas 1 [PIV] e Pelotas 2 [P2V]) foi detectada. Considerando a rara ocorrência da infecção pelo VACV em equinos, o objetivo deste estudo foi investigar a susceptibilidade e a patogenia experimental da infecção pelo VACV nessa espécie. Para isso, seis equinos adultos foram inoculados com P1V ou P2V $\left(10^{6,3} \mathrm{DICC}_{50} \mathrm{ml}\right)$ após escarificação na superficie nasolabial e monitorados para os aspectos virológicos, clínicos e patológicos por 28 dias. Quatro animais inoculados (4/6) desenvolveram lesões macroscópicas leves nos locais da inoculação, consistentes com aquelas causadas por VACV, caracterizadas por úlceras e crostas focais restritas à área inoculada, entre os dias 2 e 8 pós-inoculação (pi). Microscopicamente, havia acantose, degeneração hidrópica do estrato espinhoso e necrose da epiderme, com bactérias intralesionais. Infiltração moderada de neutrófilos, macrófagos e linfócitos foi observada na derme superficial. Inclusões intracitoplasmáticas eosinofilicas foram infrequentemente observadas nos queratinócitos degenerados adjacentes às áreas necróticas. Excreção viral foi detectada por PCR e isolamento viral das lesões de um equino inoculado com o $P 2 \mathrm{~V}$, entre os dias 4 e 8pi. Não foi detectada produção de anticorpos especificos para o VACV em nenhum animal inoculado. Em resumo, a inoculação de cavalos com os isolados P1V e P2V resultou em um baixo nível de replicação viral e em baixa frequência, resultando em lesões cutâneas mais discretas em comparação com outras espécies susceptiveis ao VACV. Apesar dos equinos serem susceptiveis à

\footnotetext{
'Laboratório de Anatomia Patológica, Hospital Veterinário de Uberaba, Universidade de Uberaba (UNIUBE), Uberaba, MG, Brasil.

ILaboratório de Diagnóstico Patológico Veterinário (LDPV), Hospital Veterinário de Grandes Animais, Universidade de Brasília (UnB), SRB, Área Especial, Galpão 4, Granja do Torto, 70636-020, Brasília, DF, Brasil. E-mail: santanafjf@yahoo.com. *Corresponding author. IIISetor de Virologia, Departamento de Medicina Veterinária Preventiva, Universidade Federal de Santa Maria (UFSM), Santa Maria, RS, Brasil.

${ }^{\text {IV }}$ Curso de Medicina Veterinária, Universidade Federal de Juiz de Fora (UFJF), Juiz de Fora, MG, Brasil. Received 02.28.15 Approved 08.13.15 Returned by the author 10.17.15
} CR-2015-0289.R4 
infecção pelo $V A C V$, possivelmente apresentam baixo potencial de manutenção e de transmissão do virus para outras espécies.

Palavras-chave: $V A C V$, infecção experimental, equinos, vaccinia bovina.

\section{INTRODUCTION}

Vaccinia virus (VACV) belongs to family Poxviridae, genus Orthopoxvirus, and is associated with exanthematic and vesicular disease mainly in cattle, but also in man and, possibly in wild and peridomestic rodents (TRINDADE et al., 2007; ABRAHÃO et al., 2009; BORGES et al., 2013; PERES et al., 2013). Natural infection by VACV in horses was reported in Brazil, yet it seems to be a rare event (BRUM et al., 2010; MATOS et al., 2013).

VACV is the etiological agent of bovine vaccinia, a zoonotic and emerging disease with great importance in dairy cattle and public health in some Brazilian regions (TRINDADE et al., 2007; KROON et al., 2011; SANT'ANA et al., 2013). The VACV disease is characterized by vesicular, pustular, and scabby lesions in udder and teats of cows, or in muzzle and oral cavity of suckling calves (LOBATO et al., 2005; SANT'ANA et al., 2013). Human lesions occur mainly in milkers, affecting hands and arms after direct contact with vesicular fluid from teats of infected cows (LOBATO et al., 2005; SILVAFERNANDES et al., 2009; ESSBAUER et al., 2010; ABRAHÃO et al., 2010a). In the last years, many cases of human disease associated with bovine vaccinia were reported in some Brazilian states, such as São Paulo, Minas Gerais, Rio de Janeiro, and Goiás (TRINDADE et al., 2006; SILVA-FERNANDES et al., 2009; SANT'ANA et al., 2013). The disease produces economic losses due to medical treatment of sick people in addition to days out of work. Decrease in milk production due to VACV infection may reach $50 \%$. Losses in dairy cattle also include expenses with veterinary care and secondary infections of teats (mastitis) that can also affect milk production (LEITE et al., 2005; LOBATO et al., 2005; LUDOLFO DE OLIVEIRA et al., 2010).

The natural cycle of VACV infection is not completely known, yet the participation of wild/peridomestic rodents as reservoirs had been suggested (ABRAHÃO et al., 2009; BORGES et al., 2013; PERES et al., 2013). If this were the case, peridomestic rodents could transmit the virus to farm animals and then to man (ABRAHÃO et al., 2009).

Although vesicular and exanthematic outbreaks occur frequently in dairy cattle in Brazil, $\mathrm{VACV}$ infection is rare in horses (KAMINJOLO Jr. et al., 1974; BRUM et al., 2010). Nonetheless, in 2008 a VACV outbreak, caused by two genetic and phenotypically divergent isolates was described in horses from Southern Brazil (BRUM et al., 2010; CAMPOS et al., 2011). The disease was characterized by ulcerative, scabby, and hemorrhagic lesion in the muzzle and mucocutaneous junction of mouth and nostrils (BRUM et al., 2010). Furthermore, serological and epidemiological studies in Brazilian equine herds showed the presence of antibodies antiOPV in animals from Midwest Brazil (BORGES et al., 2013; PERES et al., 2013). Recently, another VACV outbreak in horses was identified in Minas Gerais (MATOS et al., 2013), with clinical course similar to the VACV outbreak reported in Southern Brazil (BRUM et al., 2010).

There are no reports of experimental VACV infection in horses using viruses isolated from this species. Therefore, considering the potential involvement of horses in the epidemiology of VACV, the objectives of this study were to evaluate the susceptibility of horses to VACV and to describe the pathogenesis of the experimental infection.

\section{MATERIAL AND METHODS}

The experiment followed a randomized design in which the hypotheses were: null $\left(\mathrm{H}_{0}\right)$, the virus will replicate and produce macro and microscopic lesions in the horses; and alternative $\left(\mathrm{H}_{1}\right)$, the virus will not replicate and will not produce lesions in the experimental animals. As no populational inference would be derived thereof, a non-probabilistic, convenience sampling was used. Data obtained from testing of biological material were classified statistically as qualitative variables.

To investigate the hypotheses, seven horses (male, adult and castrated) were used. The animals were allocated in two groups according to the VACV inoculum, in addition to a control animal (CNT). The VACV isolates used for inoculation were Pelotas 1 (VACV-P1V) and Pelotas 2 (VACV-P2V), passage 4, amplified in Vero cells (derived from the kidney of an African green monkey, ATCC ${ }^{\circledR}$ CCL-81). Animals C1V1, C3V1 and C5V1 were inoculated with VACV$\mathrm{P} 1 \mathrm{~V}$; animals $\mathrm{C} 2 \mathrm{~V} 2, \mathrm{C} 4 \mathrm{~V} 2$ and $\mathrm{C} 6 \mathrm{~V} 2$ were inoculated with VACV-P2V; and the CNT animal was inoculated with minimal essential medium (MEM). All animals were housed in individual stables and they received daily $8 \mathrm{~kg}$ of forage and $2 \mathrm{~kg}$ of concentrate in two meals and water ad libitum.

For virus inoculation and punch biopsies, the animals were sedated with xylazine hydrochloride 
$10 \%(1 \mathrm{mg} / \mathrm{kg})$. In addition, $5 \mathrm{ml}$ of lidocaine $2 \%$ was injected in the infraorbital foramen for local anesthesia. Virus inoculation was done in the left planum nasolabial and in mucocutaneous junction of left superior lip through the scarification of the skin using a $40 \times 12 \mathrm{~mm}$ sterile needle. Scarified area was approximately $1.5 \mathrm{~cm}^{2}$ and received $400 \mu \mathrm{L}$ of MEM containing $10^{6.3} \mathrm{TCID}_{50} \mathrm{ml}^{-1}$ of the virus $(50 \%$ tissue culture infectious dose per milliliter).

Total blood, sera and swabs from inoculated areas were collected at days $0,2,4,6,8,10,12,14$, 21 and 28pi. Swabs were submitted to virus isolation in Vero cells to detect virus shedding. PCR to VACV $v g f$ gene (ABRAHÃO et al., 2010b) were performed using blood samples (to detected viremia) and swabs. Sera from animals (days 0 and 28 pi) were submitted to virus neutralization to orthopoxvirus. All virological tests were performed according to the methodology described by CARGNELUTTI et al. (2012b).

At days 4, 6, 8 and 10pi $6 \mathrm{~mm}$ punch biopsies were taken from lesion and adjacent healthy skin. The samples were fixed in $10 \%$ buffered formalin, embedded in paraffin, sectioned at $5 \mu \mathrm{m}$, stained with hematoxilin and eosin (H\&E), and submitted to microscopic examination.

After 28 days pi the animals were submitted to euthanasia and necropsy. Tissue fragments of liver, heart, lungs, mouth, stomach, lymph nodes, spleen, kidney, brain and muzzle skin were collected for histopathology.

\section{RESULTS AND DISCUSSION}

Inoculation of horses with VACV-P1V $(n=3)$ and VACV-P2V $(n=3)$ resulted in mild and focal lesions in four animals (two animals inoculated with each virus), characterized by papules, ulcers and mild scabs. The clinical course was 3 to 4 days in most animals, with 6 days (2-8 days pi.) in horse $\mathrm{C} 2 \mathrm{~V} 2$, inoculated with VACV-P2V. Furthermore, viral shedding (virus isolation and PCR positivity) was also present in this animal between days 2 and 8pi. No infectious virus was detected in the other animals. No neutralizing antibodies were detected in the inoculated horses at day 28pi. Failure to detect neutralizing antibodies in the animals is probably due to the very low levels of virus replication in the skin.

The chronological evolution of macroscopic lesions is shown in figure 1 (A-D). At day 2pi, animal C2V2 presented papules of 5 to $10 \mathrm{~mm}$ in diameter, with depressed or ulcerated centers and slightly raised edges in the mucocutaneous junction of the upper left lip (inoculation site). At day 4pi, this animal presented a $0.8 \mathrm{~cm}$ ulcer below the left nostril (Figure 1B). At the same day, the horse C1V1 had two similar ulcers, a $0.5 \mathrm{~cm}$ in diameter in the left nostril and a $1.0 \mathrm{~cm}$ in diameter in the left lip. Lesions of horse $\mathrm{C} 1 \mathrm{~V} 1$ healed faster than those from $\mathrm{C} 2 \mathrm{~V} 2$ (less than 2 days). After 5 days pi C3V1 and $\mathrm{C} 6 \mathrm{~V} 2$ presented $0.3 \mathrm{~cm}$ ulcers in the left planum nasolabial and left superior lip. At day 7pi no lesions were observed in these animals. Macroscopic lesions (scabs and serous fluid) remained until day 8pi only in $\mathrm{C} 2 \mathrm{~V} 2$. At day 10pi all lesions were healed in the latter animal. There were no gross findings in animals C4V2 and C5V1 during the 28 days of experiment.

Macroscopic lesions were observed between days 2 and 8pi, with an average of 3 to 4 days. The clinical course in this study was shorter than those reported by BRUM et al. (2010), where it was detected lesions and clinical signs during 6 to 12 days. They described papules in the nostrils, muzzle and mucosal surface of the lips. Thus, the VACV experimentally infected horses from the present study developed lesions compatible with the findings of BRUM et al. (2010) in naturally infected horses, yet with shorter and milder clinical course. Other reports demonstrated more severe lesion development, when compared to the present report. STUDDERT (1989) experimentally infected horses with VACV "Gilliard strain" and observed a severe multifocal to coalescent distribution of 2 to $4 \mathrm{~mm}$ pustules with hemorrhagic center at the site of inoculation. In addition, the clinical course was longer, with healing observed only at day 22pi. It is likely that the VACV strain used by STUDDERT (1989) was more virulent to horses than the isolates $\mathrm{P} 1 \mathrm{~V}$ and $\mathrm{P} 2 \mathrm{~V}$ used in this investigation.

In rabbits and mice, experimental VACV infection resulted in more severe lesions and earlier onset of clinical signs. Mice (FERREIRA et al., 2008) and rabbits (CARGNELUTTI et al., 2012b) with intranasal inoculation presented clinical signs in the first (rabbits) or second day pi (mice). Intradermal VACV inoculation in rabbits with the same isolates (VACV-P1V or VACV-P2V) or with a combination of them (VACV-P1V + VACV-P2V) resulted in moderate to severe lesions characterized by hyperemia, macules, papules, vesicles, and ulcers with serous-hemorrhagic secretion. After 30 days pi, some animals still presented scars. In the same report, the animals from experimental group inoculated with combined VACV-P1V + VACV-P2V isolates, presented local and systemic signs more severe than animals inoculated with individual isolates. These findings suggest that VACV coinfection results in the development of more severe lesions when 


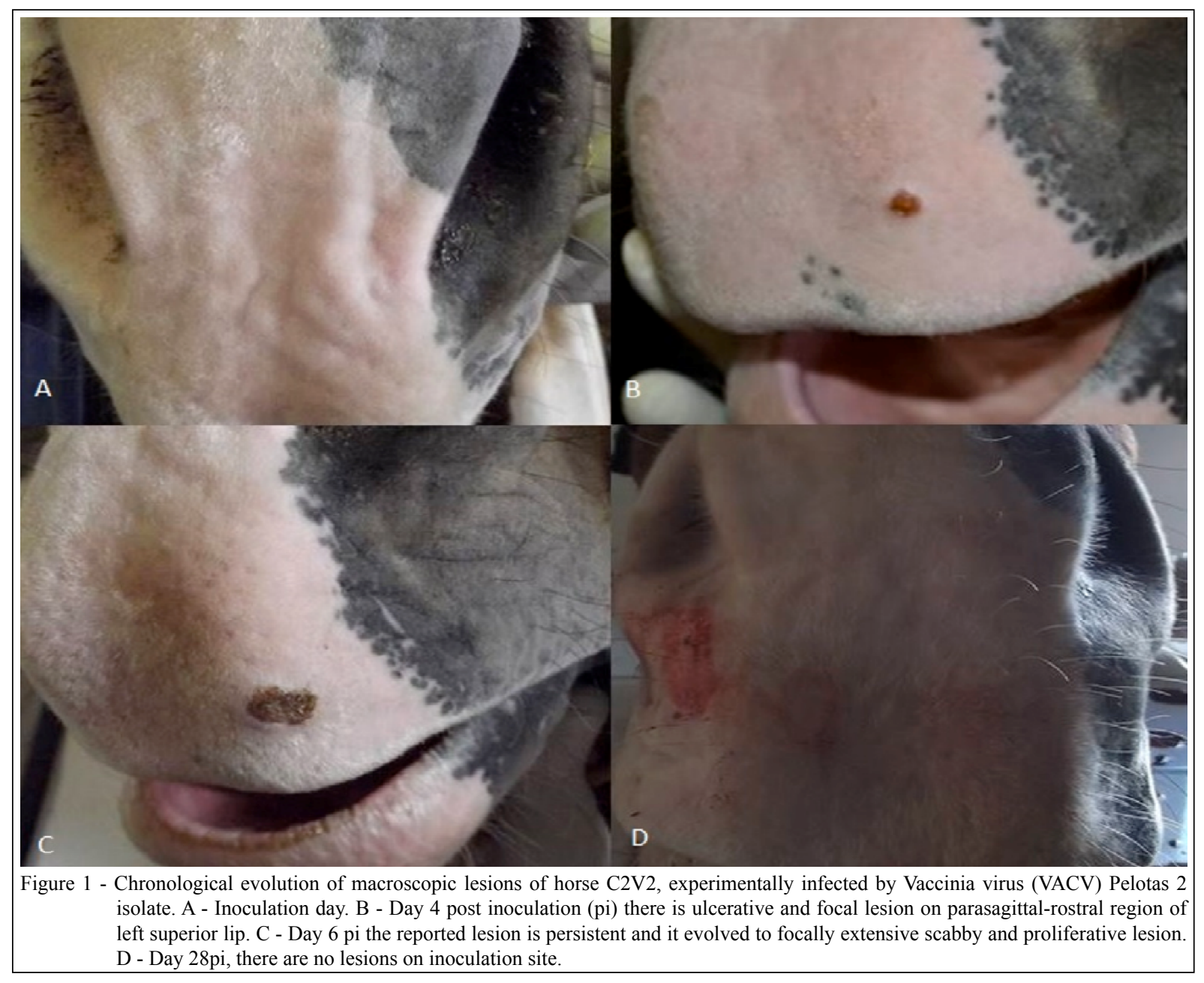

compared with infections caused by a single VACV isolate (CARGNELUTTI et al., 2012a). In contrast to observed in rabbits and mice inoculated with VACV-P1V and P2V, our results showed that horses inoculated with the same isolates presented milder lesions, and did not die after virus replication.

The pathogenesis of VACV infection in cattle was investigated in eight dairy cows inoculated with VACV-GP2V via scarification of the teats (RIVETTI Jr et al., 2013). All animals developed lesions compatible with VACV in naturally infected cows. Lesions were initially observed around $2^{\text {nd }}$ day pi and healed in 18 days. Although there are experimental studies of VACV infection in cattle, there were no reports on experimental infection of horses with VACV isolates recovered from the same species.

Microscopically, the results of the present study were compatible with those lesions caused by OPV infection. The chronological evolution of microscopic findings is shown in figure 2 (A-D). At day 4pi, animals C1V1 and C2V2 had acanthosis, mild multifocal acantholysis and moderate focal hyperkeratosis, with focally extensive loss of epidermal layers (ulcer) and focally extensive necrosis with intralesional aggregate of basophilic coccoid bacteria (Figure 2A e 2C). There was moderated focally extensive ballooning degeneration. At superficial dermis there was focally extensive infiltrate with numerous degenerated and intact neutrophils, and few macrophages and lymphocytes. Animal C2V2 had more severe lesions than the other animals. Intracytoplasmic eosinophilic inclusions were infrequently observed in degenerate keratinocytes adjacent to areas of necrosis in the same horse (Figure 2B). At $6^{\text {th }}$ day pi, animal C6V2 presented focally extensive crusting and ballooning degeneration of keratinocytes. At the same day, the animal $\mathrm{C} 3 \mathrm{~V} 1$ had no microscopic lesion. At day 8pi, the animals $\mathrm{C} 1 \mathrm{~V} 1$ and $\mathrm{C} 2 \mathrm{~V} 2$ presented small focal scabs, ulcers, and moderate infiltration of

Ciência Rural, v.46, n.3, mar, 2016. 


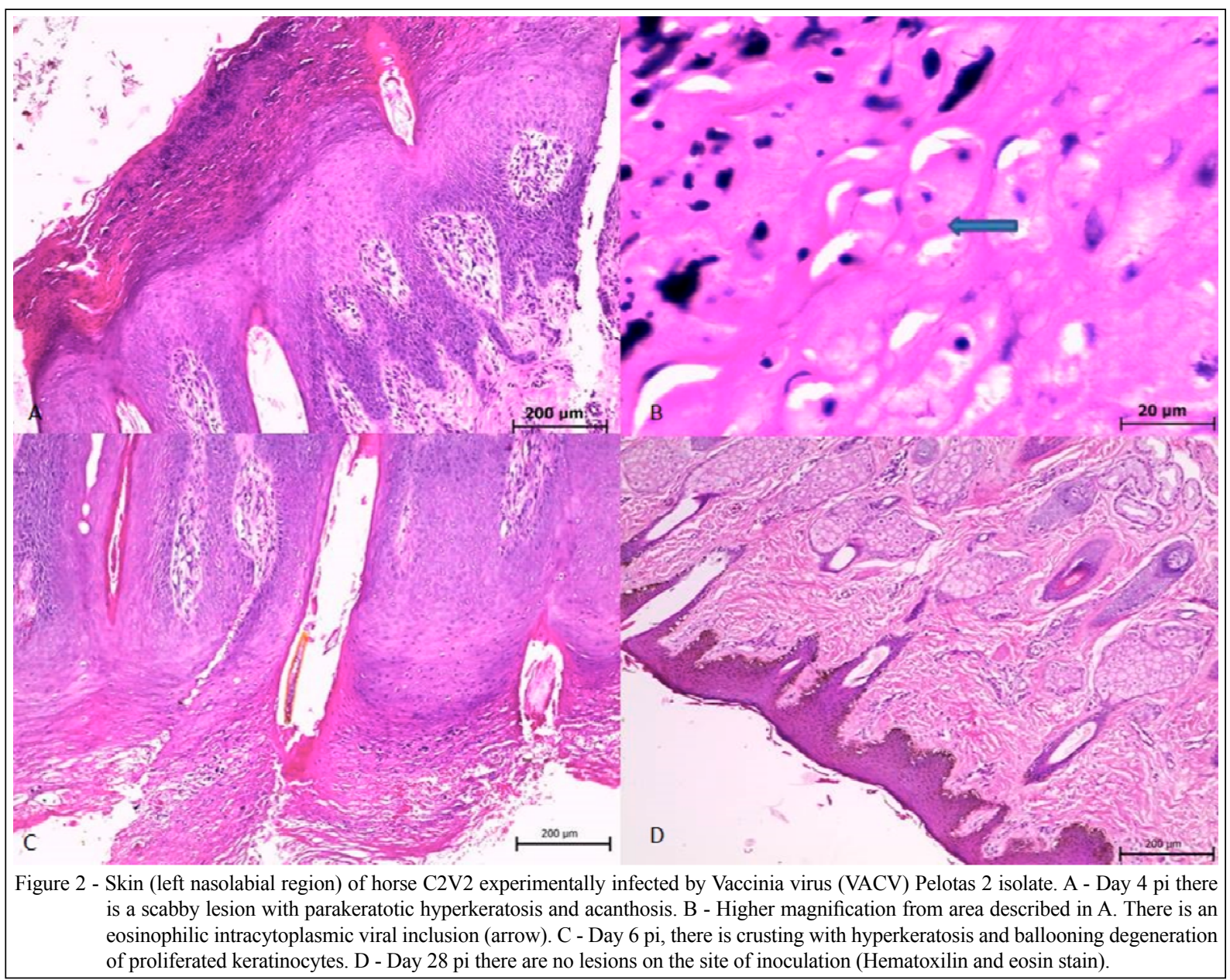

neutrophils, macrophages, and lymphocytes. At $10^{\text {th }}$ day pi, horses C4V2 and C5V1 had no microscopic lesions. These microscopic findings are agreement with STUDDERT (1989). However, lesion severity differs, since STUDDERT (1989) described more severe macro and microscopic findings. In addition, VACV (P1V and P2V) infection in horses from this experiment, resulted in lesions macro and microscopically milder than those observed in rabbits experimentally inoculated with the same VACV isolates. Experimentally infected rabbits developed local (skin/site of inoculation) and systemic lesions (interstitial pneumonia) (CARGNELUTTI et al., 2012a). These findings suggest that horses are less susceptible to VACV-P1V and VACV-P2V than other species (rabbits and mice). Additionally, necropsy at day 28pi and histopathology of internal organs did not demonstrated systemic lesions due to VACV infection (Figure 2D).

Virus shedding was detected only in horse C2V2, inoculated with VACV-P2V. PCR and virus isolation were positive in swab samples collected from this animal (C2V2) at days 4, 6 and 8pi, showing virus replication in inoculated site. It is possible that infectious virus/or DNA had not been detected in other inoculated animals due to absence of virus replication in inoculate site, or due to the minimal lesion development as a result of minimal virus replication. Even occurred minimal lesions in inoculated animals, it was proved by virus quantification that inoculum had enough amount of infectious virus to produce lesions $\left(10^{6.3} \mathrm{TCID}_{50} \mathrm{ml}^{-1}\right)$.

In a previous study (CARGNELUTTI, 2014, personal communication), two horses were inoculated in nostril/muzzle with approximately $10^{6} \mathrm{TCID}_{50} \mathrm{ml}^{-1}$ of VACV isolates P1V and P2V. No macroscopic lesions, virus shedding or seroconversion were observed in inoculated horses. These results reinforced that VACV-P1V and VACV$\mathrm{P} 2 \mathrm{~V}$ do not replicate well in healthy horses. Both experiments used healthy horses without recent history of immunosuppression. Since the isolates

Ciência Rural, v.46, n.3, mar, 2016. 
VACV-P1V and VACV-P2V were recovered from horses with moderate to severe disease (BRUM et al., 2010), it is probable that the severity of the natural outbreak could be related to a deficient immune status of the animals. However, there is no sufficient information from the reported outbreak to confirm this supposition.

\section{CONCLUSION}

Healthy horses present mild cutaneous lesions after experimental infection by VACV-P1V and VACV-P2V, suggesting that horses are less likely to serve as reservoirs and sources of VACV infection for other species in nature.

\section{ACKNOWLEDGEMENTS}

Coordenação de Aperfeiçoamento de Pessoal de Nível Superior (CAPES) and Conselho Nacional de Desenvolvimento Científico e Tecnológico $(\mathrm{CNPq})$ by financial support, and the Laboratory of Veterinary Pathology from UnB, and Virology Section of UFSM. J.F. Cargnelutti and E.F. Flores had CNPq research fellowship.

\section{REFERENCES}

ABRAHÃO, J.S. et al. One more piece in the VACV ecological puzzle: could peridomestic rodents be the link between wildlife and bovine vaccinia outbreaks in Brazil? PLoS One, v.4, p.e7428, 2009. Available from: <http://journals.plos.org/plosone/ article?id=10.1371/journal.pone.0007428>. Accessed: Sept. 15, 2015. doi: 10.1371/journal.pone.0007428.

ABRAHÃO, J.S. et al. Human vaccinia virus and pseudocowpox virus co-infection:clinical description and phylogenetic characterization. Journal of Clinical Virology, v.48, p.69-72, 2010a. Available from: <http://www.journalofclinicalvirology. com/article/S1386-6532(10)00052-1/abstract>. Accessed: Sept. 15, 2015. doi: 10.1016/j.jcv.2010.02.001.

ABRAHÃO, J.S. et al. Rapid detection of Orthopoxvirus by seminested PCR directly from clinical specimens: a useful alternative for routine laboratories. Journal of Medical Virology, v.82, p.692-699, 2010b. Available from: <http://onlinelibrary.wiley. com/doi/10.1002/jmv.21617/pdf>. Accessed: Sept. 15, 2015. doi: $10.1002 / \mathrm{jmv} .21617$

BORGES, I.A. et al. Evaluation of Orthopoxvirus circulation among equids from Minas Gerais State, Brazil: Serological and historical implications. In: BRAZILIAN CONGRESS OF VIROLOGY, 24., 2013, Porto Seguro. Anais eletrônicos... Virus Reviews and Research, 18 (supl. 1). Available from: $<$ http://www. sbv.org.br/vrr/ISSUE18.pdf>. Accessed: Oct. 02, 2013.

BRUM, M.C.S. et al. An outbreak of orthopoxvirus-associated disease in horses in southern Brazil. Journal of Veterinary Diagnostic Investigation, v.22, p.143-147, 2010. Available from: <http://vdi.sagepub.com/content/22/1/143.full.pdf+html $>$. Accessed: Sept. 15, 2015. doi: 10.1177/104063871002200132.
CAMPOS, R.K. et al. Assessing the variability of brazilian vaccinia virus isolates from a horse exanthematic lesion: coinfection with distinct viruses. Archives of Virology, v.156, p.275-283, 2011. Available from: <http://link.springer.com/ article/10.1007\%2Fs00705-010-0857-z>. Accessed: Sept. 15, 2015. doi: $10.1007 / \mathrm{s} 00705-010-0857-\mathrm{z}$.

CARGNELUTTI, J.F. et al. Vaccinia viruses isolated from skin infection in horses produced cutaneous and systemic disease in experimentally infected rabbits. Research in Veterinary Science, v.93, p.1070-1075, 2012a. Available from: <http:// www.sciencedirect.com/science/article/pii/S0034528811005054>. Accessed: Sept. 15, 2015. doi: 10.1016/j.rvsc.2011.12.016.

CARGNELUTTI, J.F. et al. Vaccinia viruses isolated from cutaneous disease in horses are highly virulent for rabbits. Microbial Pathogenesis, v.52, p.192-199, 2012b. Available from: <http://www.sciencedirect.com/science/article/pii/ S0882401011002191>. Accessed: Sep. 15, 2015. doi: 10.1016/j. micpath.2011.12.005.

ESSBAUER, S. et al. Zoonotic poxviruses. Veterinary Microbiology, v.140, p.229-236, 2010. Available from: <http:// www.sciencedirect.com/science/article/pii/S0378113509003988>. Accessed: Sep. 15, 2015. doi: 10.1016/vetmic.2009.08.026.

FERREIRA, J.M.S. et al. Vaccinia virus: shedding and horizontal transmission in a murine model. Journal of General Virology, v.89, p.2986-2991, 2008. Available from: <http://jgv.sgmjournals. org/content/journal/jgv/10.1099/vir.0.2008/003947-0\#tab2> Accessed: Sep. 15, 2015. doi: 10.1099/vir.0.2008/003947-0.

KAMINJOLO JR., J.S. et al. Vaccinia-like pox virus identified in a horse with a skin disease. Zentralbl Veterinarmed B, v.21, p.202-206, $1974 f$.

KROON, E.G. et al. Zoonotic Brazilian vaccinia virus: from field to therapy. Antiviral Research, v.92, p.150-163, 2011. Available from: $<$ http://www.sciencedirect.com/science/article/pii/ S0166354211004190>. Accessed: Sept. 15, 2015. doi: 10.1016/j. antiviral.2011.08.018.

LEITE, F.A. et al. Passatempo virus, a vaccinia virus strain, Brazil. Emerging Infectious Diseases, v.11, p.1935-1938, 2005. Available from: <http://wwwnc.cdc.gov/eid/article/11/12/05-0773 article>. Accessed: Sept. 15, 2015. doi: 10.3201/eid1112.050773.

LOBATO, Z.I.P. et al. Outbreak of exantemal disease caused by Vaccinia vírus in human and cattle in Zona da Mata region, Minas Gerais. Arquivo Brasileiro de Medicina Veterinária e Zootecnia, v.57, p.423-429, 2005. Available from: <http://www. scielo.br/pdf/abmvz/v57n4/26061.pdf>. Accessed: Sept. 15, 2015. doi: 10.1590/S0102-09352005000400001.

LUDOULFO DE OLIVEIRA, T.M. et al. Vaccinia virus is not inactivated after thermal treatment and cheese production using experimentally contaminated milk. Foodborne Pathogens and Disease, v.7, p.1491-1496, 2010. Available from: <http:// online.liebertpub.com/doi/abs/10.1089/fpd.2010.0597?url_ ver $=$ Z39.88-2003\&rfr_id=ori\%3Arid\%3Acrossref.org \& rfr dat $=$ cr_pub\%3Dpubmed $>$. Accessed: Sept. 15, 2015. doi: $10.1089 /$ fpd.2010.0597.

MATOS, A.C.D. et al. Outbreak of vaccinia virus infections in horses in Minas Gerais State,Brazil. In: BRAZILIAN CONGRESS OF VIROLOGY, 24., 2013, Porto Seguro. Anais eletrônicos... 
Virus Reviews and Research, 18 (supl. 1). Available from: < http:// www.sbv.org.br/vrr/ISSUE18.pdf>. Accessed: Oct. 02, 2013.

PERES, M.G et al. Serological study of vaccinia virus reservoirs in areas with and without official reports of outbreaks in cattle and humans in São Paulo, Brazil. Archives of Virology, v.158, p.2433-2441, 2013. Available from: <http://link.springer.com/art icle/10.1007\%2Fs00705-013-1740-5>. Accessed: Sept. 15, 2015. doi: $10.1007 / \mathrm{s} 00705-013-1740-5$.

RIVETTI JR, A.V. et al. Bovine vaccinia, a sistematic infection: evidence of a fecal shedding, viremia and detection in lymphoid organs. Veterinary Microbiology, v.162, p.103-111, 2013. Available from: $<$ http://www.sciencedirect.com/science/article/pii/ S0378113512005032>. Accessed: Sept. 15, 2015. doi: 10.1016/j. vetmic.2012.09.005

SANT'ANA, F.J.F. et al. Outbreaks of vesicular disease caused by Vaccinia virus in dairy cattle from Goiás State, Brazil (2010-2012). Pesquisa Veterinária Brasileira, v.33, p.860-866, 2013. Available from: <http://www.scielo.br/pdf/pvb/v33n7/06.pdf $>$. Accessed: Sept. 15, 2015. doi: 10.1590/S0100-736X2013000700006.
SILVA-FERNANDES, A.T.et al. Natural human infections with vaccinia virus during bovine vaccinia outbreaks. Journal of Clinical Virology, v.44, p.308-313, 2009. Available from: $<$ http://www.journalofclinicalvirology.com/article/S13866532(09)00037-7/abstract>. Accessed: Sept. 15, 2015. doi: 10.1016/j.jcv.2009.01.007.

STUDDERT, M.J. Experimental vaccinia virus infection of horses. Australian Veterinary Journal, v.66, p.157-158, 1989.

TRINDADE, G.S.et al. Brazilian vaccinia viruses and their origins. Emerging Infectious Disease, v.13, p.965-972, 2007. Available from: <http://wwwnc.cdc.gov/eid/content/13/7/pdfs/v13-n7.pdf>. Accessed: Sep. 15, 2015. doi: 10.3201/eid1307.061404.

TRINDADE, G.S. et al. Short report: isolation of two vaccinia virus strains from a single bovine vaccinia outbreak in rural area from Brazil: implications on the emergence of zoonotic orthopoxviruses. American Society of Tropical Medicine and Hygiene, v.75, p.486-490, 2006. Available from: <http://www.ajtmh.org/content/75/3/486. long $>$. Accessed: Sept. 15, 2015. 